\title{
Studies on toxin and enzymatic effect of Curvularia andropogonis in Lemon grass
}

\author{
Vandana* and N. Lakpale \\ Department of Plant Pathology, College of Agriculture, \\ Indira Gandhi Krishi Vishwavidyalaya, Raipur, Chhattisgarh, 492012 \\ *Corresponding author
}

\section{A B S T R A C T}

Keywords

Curvularia andropogonis, CMC, Cellulase, Vegetable pith

Article Info

Accepted:

11 June 2020

Available Online:

10 July 2020
The enzymatic activity resulting degradation of CMC was found maximum $(34.60 \%)$ at $\mathrm{pH} 4.2$ by the culture filtrate of Curvularia andropogonis. The enzymatic activity was recorded starting from 15 minutes upto 150 minutes. Maceration of vegetable pith was found faster at $100 \%$ concentration of culture filtrate in potato pith followed by carrot and pumpkin pith.

\section{Introduction}

Curvularia leaf blight is the most serious disease of lemon grass causing greater loss in yield by affecting the leaves of the crop. To investigate the toxin and enzymatic effect of Curvularia andropogonis on the cell wall of the host containing cellulose, this experiment was carried out at Indira Gandhi Krishi Vishwavidyalaya, Raipur during 2019-2020.

\section{Materials and Methods}

\section{Determination of Cellulase Activity}

Cellulase activity of the pathogen was determined by measuring the reduction in viscosity of CMC solution. The viscometric measurements were recorded at the time intervals of $0,15,30,45,60,75,90,105,120$, 135 and 150 minutes. The reaction mixture consisted of the following :

$5 \mathrm{ml}$ of 0.5 per cent carboxy methyl cellulose solution.

$2 \mathrm{ml}$ of sodium citrate buffer (at $\mathrm{pH}$ level of 4.2, 7.2 and 9.2).

$2 \mathrm{ml}$ of enzymatic preparation (Pathogen culture filtrate).

The calculation of reduction in viscosity of $\mathrm{CMC}$ can be done by the formula: 
$\%$ loss in viscosity $=\frac{\mathrm{T}_{0}-\mathrm{T}_{1}}{\mathrm{~T}_{0}-\mathrm{T}_{\mathrm{w}}} \times 100$

Where,

$\mathrm{T}_{0}=$ Flow time of reaction mixture at " 0 " minute

$\mathrm{T}_{1}=$ Flow time of reaction mixture at a particular time interval

$\mathrm{T}_{\mathrm{w}}=$ Flow time of distilled water

\section{Preparation of culture filtrate}

Culture filtrate was made by using potato dextrose broth as a medium. After autoclaving, the medium was inoculated with $7 \mathrm{~mm}$ disc of seven days old culture of the test pathogen. After ten days culture of the pathogen grew and covered the upper layer of the medium, it was filtered with the help of Whatman filter paper and the obtained culture filtrate was used for enzymatic study.

\section{Macerating enzymes}

For estimation of macerating enzymes present in the pathogen, five different concentrations (viz.100\%, 80\%, 60\%, 40\%, 20\%) of pathogen culture filtrate were used on vegetable (potato, carrot and pumpkin) pith. Seven $\mathrm{mm}$ diameter and $1 \mathrm{~mm}$ thick disc of potato, carrot and pumpkin were prepared and sterilized with $0.1 \%$ of Mercuric chloride $\left(\mathrm{HgCl}_{2}\right)$ followed by three subsequent washings with sterilized water. Twenty $\mathrm{ml}$ of each concentration of culture filtrate was taken in a $90 \mathrm{~mm}$ Petri plate and three discs were dipped in a single Petri plate. Disc dipped in sterilized water served as control. These Petri plates were kept at room temperature. For each concentration three replications were maintained. Observation of rotting of potato and pumpkin was taken every one hour interval.

\section{Results and Discussion}

The data on the effect of the culture filtrate of Curvularia andropogonis on the activity of $\mathrm{CMC}$ at different $\mathrm{pH}$ levels are given in Table 1 , which clearly shows that the cellulolytic activities differed with the change in $\mathrm{pH}$ levels at 4.2,7.2 and 9.2 with the time interval from 0 minutes to 150 minutes. It also indicated that change in per cent loss in viscosity was related with the change in the $\mathrm{pH}$ levels. From the table, it was clear that per cent loss in viscosity was very high (34.60) at $\mathrm{pH} 4.2$ followed by 20.50 and 8.11 at $\mathrm{pH} 7.2$ and 9.2, respectively. The enzymatic reaction started from 15 minutes and became maximum at 135 to 150 minutes. It was clear that the cultural filtrate adjusted at $\mathrm{pH} 4.2$ was most suitable for rapid degradation of CMC by the enzymatic activity of Curvularia andrpogonis. This means the enzyme released by the pathogen was maximum in acidic $\mathrm{pH}$ than natural and alkaline $\mathrm{pH}$.

The data presented in table 2 revealed that as the concentration of cultural filtrate increases, the time of macerating of vegetable piths decreases and at $100 \%$ concentration potato pith rotted in $20 \mathrm{hrs}$ followed by carrot (22 hrs) and pumpkin at (26 hrs) while control took maximum time for rotting 115,123 and 148 hrs, respectively.

The findings of the above investigation were supported by the findings of Alam (1979), Binjhare (2002) and Verma (2014).

Alam (1979) studied the effect of the cellulolytic enzymes released by Curvularia andropogonis, the causal agent of leaf blight of Java citronella. Modified Richard's medium with different carbon sources (viz, sucrose, carboxy methyl cellulose, filter paper pulp) were used to obtain cultural filtrate and tested for loss of viscosity in Fenske Ostwald viscometer. Results showed 
maximum percent loss in viscosity in cultural fitrate obtained from medium containing filter paper pulp followed by medium contained carboxymethyl cellulose while no reaction was found in filtrate obtained from medium containing sucrose.

Binjhare (2002) studied the effects of the reactions caused by enzymes released by Botrytis ricini with the help of Ostwald's viscometer. Results showed the percent loss in viscosity was higher $(75.85 \%)$ at $\mathrm{pH} 4.0$ followed by $62.06 \%$ at $\mathrm{pH} 7.0$ and $13.79 \%$ at $\mathrm{pH}$ 9.0.
Verma, (2014) studied the effect of enzymatic reactions caused by Choanephora infundibulifera on cellulose (Carboxy methyl cellulose) at different $\mathrm{pH}(4.0,7.0,9.0)$ with the help of Ostwald's viscometer and on pith of potato, pumpkin and carrot at different concentration $(20,40,60,80,100 \%)$ of cultural filtrate. Results showed that the maximum degradation of carboxy methyl cellulose was observed at $\mathrm{pH} 4.0$ and for maceration of pith of potato, carrot and pumpkin $100 \%$ concentration was most effective.

Table.1 Effect of Curvularia andropogonis on the activity of Carboxy methyl cellulose (CMC) at different $\mathrm{pH}$ levels

\begin{tabular}{|c|c|c|c|}
\hline \multirow{2}{*}{$\begin{array}{c}\text { Time intervals } \\
\text { (in minutes) }\end{array}$} & \multicolumn{3}{|c|}{ Per cent loss in viscosity in different pH levels } \\
\hline $\mathbf{0}$ & $\mathbf{p H ~ 4 . 2}$ & $\mathbf{p H ~ 7 . 2}$ & $\mathbf{p H ~ 9 . 2}$ \\
\hline $\mathbf{1 5}$ & 0 & 0 & 0 \\
\hline $\mathbf{3 0}$ & 2.02 & 1.93 & 1.83 \\
\hline $\mathbf{4 5}$ & 6.31 & 2.77 & 3.14 \\
\hline $\mathbf{6 0}$ & 10.10 & 4.43 & 3.66 \\
\hline $\mathbf{7 5}$ & 13.38 & 5.26 & 4.71 \\
\hline $\mathbf{9 0}$ & 26.77 & 5.82 & 5.76 \\
\hline $\mathbf{1 0 5}$ & 28.03 & 17.73 & 6.80 \\
\hline $\mathbf{1 2 0}$ & 29.80 & 18.56 & 7.07 \\
\hline $\mathbf{1 3 5}$ & 31.06 & 19.11 & 7.33 \\
\hline $\mathbf{1 5 0}$ & 32.32 & 19.67 & 7.59 \\
\hline
\end{tabular}

Table.2 Effect of culture filtrate of Curvularia andropogonis on maceration of potato, pumpkin and carrot pith

\begin{tabular}{|c|c|c|c|}
\hline $\begin{array}{c}\text { Concentration of } \\
\text { culture filtrate (\%) }\end{array}$ & \multicolumn{3}{|c|}{ Rotting of vegetable pith (hrs.) } \\
\hline $\mathbf{2 0}$ & Potato & Pumpkin & Carrot \\
\hline $\mathbf{4 0}$ & 70 & 91 & 94 \\
\hline $\mathbf{6 0}$ & 51 & 73 & 85 \\
\hline $\mathbf{8 0}$ & 38 & 51 & 42 \\
\hline $\mathbf{1 0 0}$ & 24 & 45 & 38 \\
\hline $\begin{array}{c}\text { Control (without } \\
\text { cultural filtrate) }\end{array}$ & 20 & 26 & 22 \\
\hline
\end{tabular}


Figure.1 Effect of Curvularia andropogonis on the activity of Carboxy methyl cellulose (CMC) at different $\mathrm{pH}$ levels

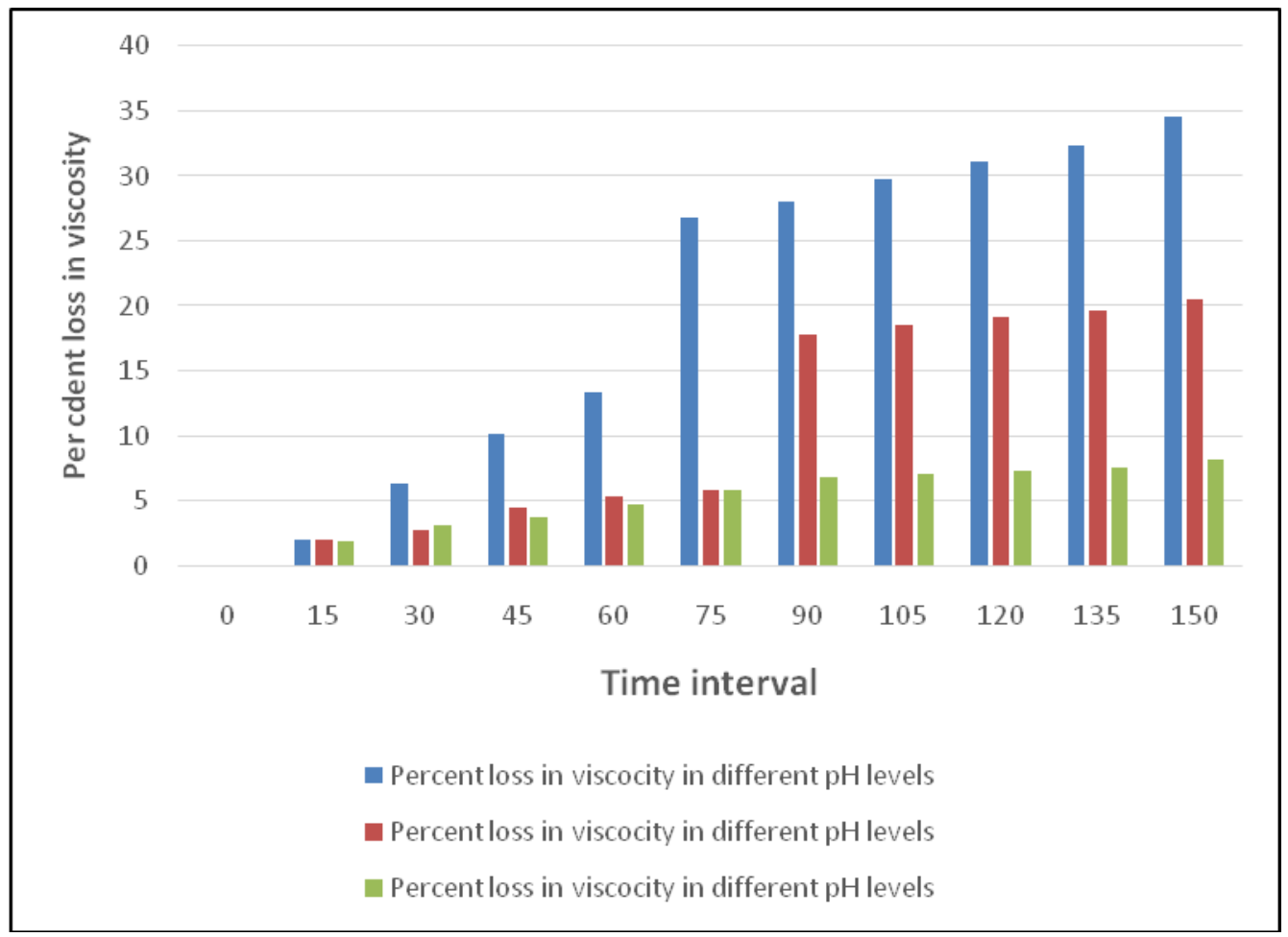

Figure.2 Effect of culture filtrate of Curvularia andropogonis on maceration of potato, pumpkin and carrot pith

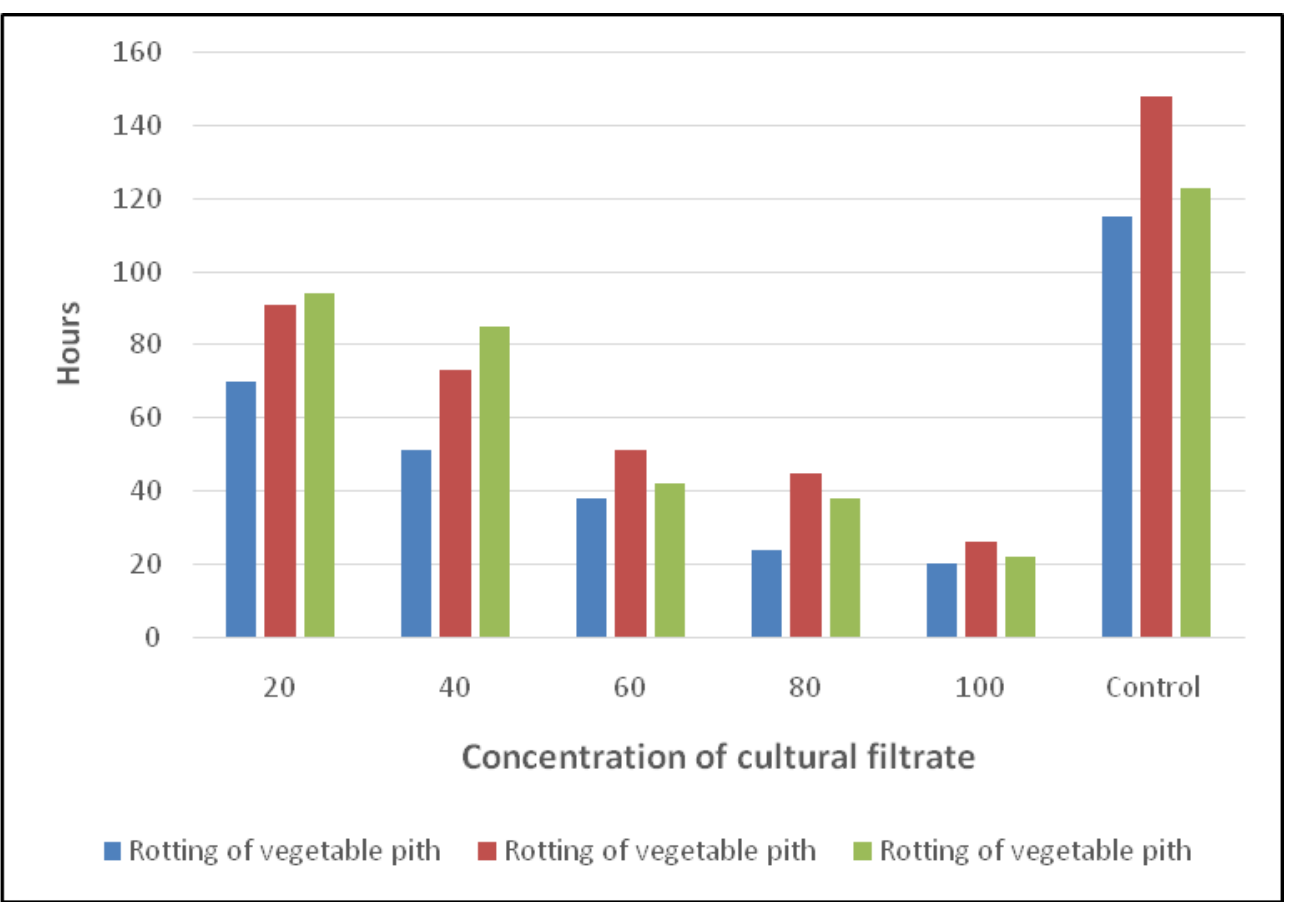




\section{References}

Alam, M. 1979. Studies on Leaf Blight Disease of Citronella Java (Cymbopogon winterianus $\mathrm{J}$ witt.) and its Control. Ph.D Thesis, Aligarh Muslim University, Aligarh. p. 55-105.

Binjhare, L.P. 2002. Studies on grey rot (Botrytis ricini Godfrey) of castor
(Ricinus communis L). M.Sc. Thesis, Indira Gandhi Krishi Vishwavidyalaya, Raipur (C.G.). p. 10-11.

Verma, K. 2014. Studies on toxin and enzymatic effect on Choanephorain fundibulifera in soybean crop. International Journal of Plant Protection. 7(1): 125-127.

\section{How to cite this article:}

Vandana and N. Lakpale. 2020. Studies on toxin and enzymatic effect of Curvularia andropogonis in Lemon grass. Int.J.Curr.Microbiol.App.Sci. 9(07): 940-944. doi: https://doi.org/10.20546/ijcmas.2020.907.109 